\title{
Correction to: Vygotsky and Psychology as Normative Science
}

\author{
Luciano Mecacci ${ }^{1}$
}

(c) Springer Science+Business Media, LLC, part of Springer Nature 2021

\section{Correction to: Integrative Psychological and Behavioral Science https://doi.org/10.1007/s12124-021-09638-4}

The original version of this article contained mistakes.

- McQueen (2006) has to be corrected into McQueen (2010)

- Leonardo \& Manning (2017) has to be put in alphabetical order.

The original article has been corrected.

Publisher's Note Springer Nature remains neutral with regard to jurisdictional claims in published maps and institutional affiliations.

The original article can be found online at https://doi.org/10.1007/s12124-021-09638-4.

\section{Luciano Mecacci}

mecaccil@gmail.com

1 Florence, Italy 